УДК 614.847.9

\title{
ОБГРУНТУВАННЯ ТЕХНІЧНИХ ВИМОГ ПОЖЕЖНОГО МАЯЧКА
}

\author{
В. С. Бенедюк, І. Г. Стилик*, О. М. Тимошенко, А. О. Грачов, О. В. Куртов
}

Український науково-дослідний інститут иивільного захисту, Україна

\section{ІНФОРМАЦІЯ ПРО СТАТТЮ}

Надійшла до редакції: 14.05.2019

Пройшла рецензування: 31.05.2019

\section{КЛЮЧОВІ СЛОВА:}

пожежний маячок, світлодіод, технічні вимоги, світлотехнічні характеристики, димова камера, фотометрична інтегруюча сфрера.

\begin{abstract}
АНОТАЦІЯ
Розглянуто питання щодо необхідності створення пожежного маячка. Обґрунтовано технічні вимоги до пожежного світлового маячка 3 урахуванням основних недоліків в існуючих моделях світлових аналогів. Описано будову та принцип роботи експериментального зразка пожежного маячка. Наведено результати експериментальних досліджень з визначення світлотехнічних характеристик пожежних маячків при роботі у задимленому середовищі різної оптичної щільності.
\end{abstract}

Під час ліквідації пожеж 3 обмеженою видимістю, у будівлях зі складними планувальними рішеннями тощо досить важко визначити осередок горіння чи місце події. При цьому пошук зворотного шляху та проведення евакуації людей $[1,2]$, які опинились у небезпечній зоні, $є$ ще більшою проблемою, що ускладнюється фізичною втомою рятувальників та вкрай сильним психологічноемоційним навантаженням. Крім того, ланка газодимозахисної служби (ГДЗС), як правило, має обмежений час для зворотного виходу, який визначається за залишком повітря (кисню) в індивідуальних засобах захисту органів дихання та зору. Проблеми орієнтації в складних умовах та фіксації зворотного шляху можуть бути частково розв'язані шляхом застосування допоміжного пожежного освітлювального та орієнтувальносвітлового устатковання.

На даний час у багатьох країнах світу (США, Китай, Франція, Ізраїль, Німеччина, РФ) пожежними підрозділами застосовується таке допоміжне устатковання, а саме:

- пожежний світловий трос;

- пожежний маячок;

- пожежні рукави з ефектом світіння.

Пожежне устатковання, що застосовується для освітлення місць ліквідації небезпечних подій та забезпечення світлового орієнтування пожежників (рятувальників) умовно можна поділити на:

- залежно від функціонального призначення: освітлювальне та орієнтувально-світлове;

- залежно від виконання: мобільне (є невід'ємною частиною транспортного засобу); переносне/передвижне (обладнане окремими конструктивними пристосуваннями для переміщення); ручне (конструкція та масо-габаритні розміри передбачають експлуатацію однією особою); портативне (для носіння на елементах спорядження);
- залежно від джерела живлення: $з$ зовнішнім електричним джерелом живлення та 3 автономним електричним джерелом живлення.

Загальний вигляд деяких зразків такого устатковання наведено на рисунку 1.

На відміну від зарубіжних країн в Україні вище наведене обладнання в підрозділах ДСНС України взагалі не використовується, а також відсутні будьякі нормативно-технічні вимоги та методи його випробувань.

Також необхідно зазначити, що у вільному доступі на Інтернет ресурсах відсутні будь-які європейські нормативні документи, в яких визначені норми та вимоги до пожежного освітлювального та орієнтувально-світлового устатковання. Можливо це зумовлено тим, що таке обладнання $\epsilon$ допоміжним, оскільки для покращення можливостей орієнтування пожежниківрятувальників у задимлених та інших об'єктах 3 обмеженою видимістю, і цілком достатніми $\epsilon$ технічні характеристики, які зазначає виробник у технічній документації на вироби.

Отже, метою представлених нижче досліджень $\epsilon$ визначення та обгрунтування світлотехнічних параметрів необхідних для створення експериментального зразка пожежного маячка, адаптованого для роботи пожежно-рятувальних підрозділів ДСНС України.

Враховуючи актуальність порушеного питання, співробітниками Українського науководослідного інституту цивільного захисту в рамках науково-дослідної роботи [3] проведено ряд аналітичних та експериментальних досліджень, метою яких було визначення світлотехнічних параметрів та виготовлення експериментального зразка пожежного маячка.

Експериментальні дослідження проводились за двома такими основними напрямами:

- визначення випромінювання світлового потоку електричних джерел світла (світлодіодів), які 
можуть бути застосовані для виготовлення експериментального зразка пожежного маячка;

- визначення ефективності проникнення світлового потоку у задимленому середовищі високої щільності.

Під поняттям задимленого середовища високої щільності мається на увазі, що згідно з даними [4] при освітлюванні груповим пожежним ліхтарем 3 лампочкою потужністю 21 Вт зі світловим потоком 400 Лм вважається, що дим є оптично щільним при умові видимості предметів 3 відстані 3 м.

Створенню експериментального зразка пожежного маячка передував патентний аналіз існуючих аналогів, на основі якого було визначено їх основні функціональні та технічні недоліки. Зокрема, це великі масо-габаритні розміри, штучні джерела світла, які мають гострий кут світіння та достатньо невисокий ККД, відсутність роз'ємів для заряджання акумуляторної батареї, при невдалому встановленні маячка або його перевертанні, падінні тощо - зменшується або взагалі відсутній ефект світлового орієнтування. Також невдалим рішенням $\epsilon$ механічне вмикання маячка. Однак основним недоліком існуючих пожежних маячків є відсутність науково-обгрунтованих світлотехнічних вимог до штучних джерел світла під час використання їх у задимленому середовищі різної оптичної щільності.

Враховуючи виявлені недоліки, було створено експериментальний зразок пожежного маячка (рисунок 2), адаптованого для роботи пожежнорятувальних підрозділів ДСНС України.
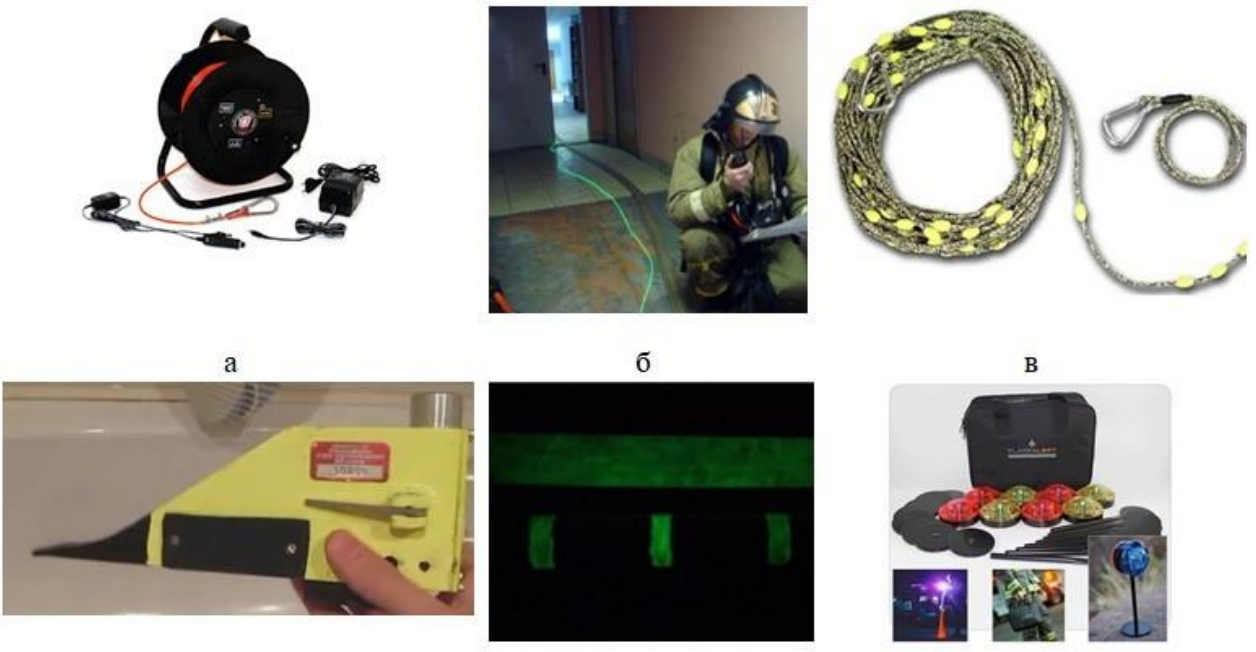

д

e

а) - пожежний світловий трос «НСТ А-100»; б) - пожежний світловий трос «Квазар-100»; в) - пожежний світловий трос «Polaris»; г) - пожежний маячок «Safety beacon»; д) - пожежний рукав; e) - пожежний маячок «Flare Alert»

Рисунок 1 - Загальний вигляд існуючого пожежного орієнтувально-світлового устатковання
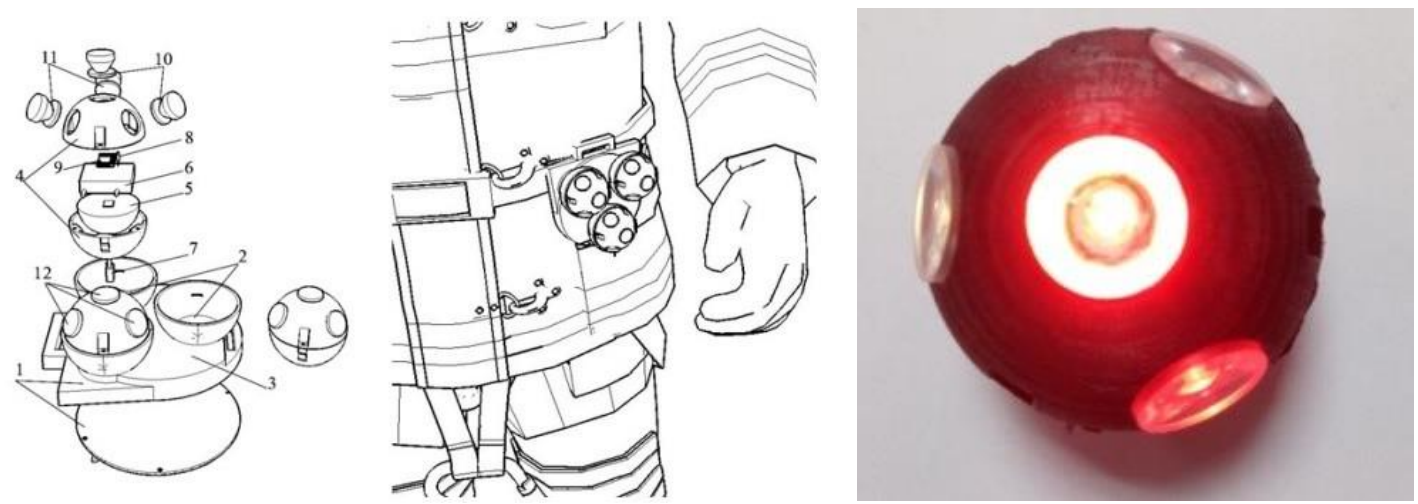

1 - корпус кріплення маячків; 2 - неодимові магніти; 3 - micro USB зарядний модуль із індикатором заряджання; 4 - корпус маячка; 5 - противага; 6 - акумуляторна батарея; 7 - роз’єм заряджання; 8 - нормально замкнутий електромеханічний геркон; 9 - електрична плата керування; 10 - світлодіоди червоних кольорів; 11 - світлодіоди теплих білих кольорів; 12 - оптичні лінзи

Рисунок 2- Загальний вигляд експериментального зразка пожежного маячка, та варіант кріплення на одязі рятувальника 
За рахунок того, що корпус маячка виконано сферичної форми із зовнішнім діаметром 55 мм, на дні (у нижній частині) якого розміщено противагу (грузило), при його використані він завжди займає положення світлодіодами доверху. Завдяки розміщенню чотирьох світлодіодів у верхній напівсфері забезпечується візуальне спостереження світіння маячка на $360^{\circ}$ відносно вертикальної осі. Автоматичне вмикання зразка відбувається в момент зняття його із корпусу кріплення завдяки використанню нормально замкнутого електромеханічного геркона та неодимових магнітів, які знаходяться в корпусі кріплення.

Електрична плата керування світлових сигналів створює електричні імпульси із частото 3 Гц та попарно живить світлодіоди в режимі мерехтіння.

На рисунку 3 наведена принципова електрична схема, яка використовується для електричного живлення світлодіодів пожежного маячка.

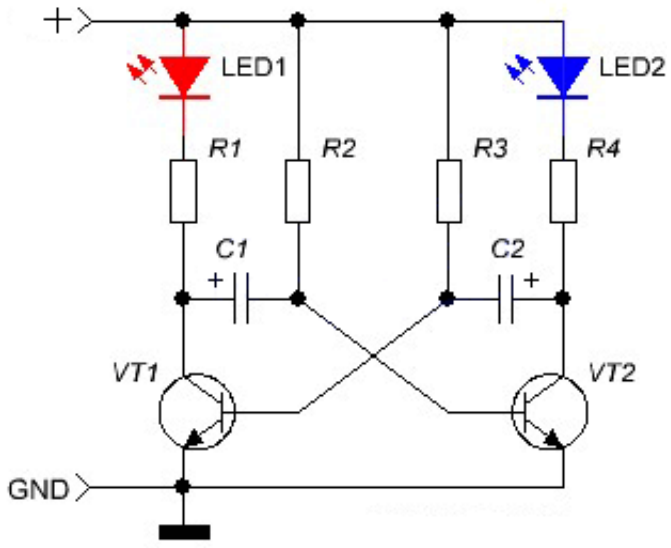

Рисунок 3 - Принципова електрична схема живлення світлодіодів пожежного маячка

Під час експериментальних досліджень щодо визначення ефективності проникнення світлового потоку у задимленому середовищі використовувались світлодіоди із різною колірною температурою світіння потужністю 1 Вт та 3 Вт, технічні параметри яких наведено в таблиці 1.

Таблиця 1 - Типи світлодіодів та їхні основні технічні характеристики

\begin{tabular}{|c|c|c|c|c|c|c|c|}
\hline \multirow{2}{*}{ Технічні параметри } & \multicolumn{7}{|c|}{ Типи світлодіодів } \\
\cline { 2 - 8 } & $\begin{array}{c}\text { Теплий } \\
\text { білий, 1Вт }\end{array}$ & $\begin{array}{c}\text { Холодний } \\
\text { білий, 1Вт }\end{array}$ & $\begin{array}{c}\text { Нейтрально } \\
\text { білий, 1Вт }\end{array}$ & $\begin{array}{c}\text { Теплий } \\
\text { білий, 3Вт }\end{array}$ & $\begin{array}{c}\text { Холодний } \\
\text { білий, 3Вт }\end{array}$ & $\begin{array}{c}\text { Нейтрально } \\
\text { білий, 3Вт }\end{array}$ & $\begin{array}{c}\text { Червоного } \\
\text { кольору, } \\
1 \text { Вт }\end{array}$ \\
\hline $\begin{array}{c}\text { Номінальний } \\
\text { світловий потік, лм }\end{array}$ & 110,0 & 110,0 & 110,0 & 220,0 & 220,0 & 220,0 & 50,0 \\
\hline $\begin{array}{c}\text { Потужність, Вт } \\
\text { Номінальна сила } \\
\text { струму, мА }\end{array}$ & 1,0 & 1,0 & 1,0 & 3,0 & 3,0 & 3,0 & 1,0 \\
\hline $\begin{array}{c}\text { Кут світіння, } \\
\text { градуси }\end{array}$ & 120,0 & 120,0 & 120,0 & 135,0 & 135,0 & 135,0 & 120,0 \\
\hline $\begin{array}{c}\text { Колірна } \\
\text { температура } \\
\text { випромінювання, К }\end{array}$ & 3500,0 & 6500,0 & 4500,0 & 3500,0 & 6500,0 & 4500,0 & 620,0 \\
\hline Розмір, мм & $8,0 \times 5,0$ & $8,0 \times 5,0$ & $8,0 \times 5,0$ & $8,0 \times 5,0$ & $8,0 \times 5,0$ & $8,0 \times 5,0$ & $8,0 \times 5,0$ \\
\hline Напруга, В & 3,2 & 3,2 & 3,2 & 3,0 & 3,0 & 3,0 & 2,25 \\
\hline
\end{tabular}

Для проведення експериментальних досліджень щодо визначення ефективності проникнення світлового потоку у задимленому середовищі високої щільності, було створено димову камеру, схема якої наведена на рисунку 4.

У димовій камері із габаритними розмірами $(1,5 \times 2,0 \times 6,0)$ м розміщувався вимірювальний комплекс для вимірювання оптичної щільності задимленого середовища (світлодіодний випромінювач CMD5050, фоторезистор та цифровий міліамперметр) за допомогою якого визначалась оптична щільність диму, вентилятор для перемішування диму в об'ємі, циліндричне деко діаметром $(170 \pm 10)$ мм із сумішшю соснової тирси, мастила та бензину для створення диму, газоаналізатор для вимірювання вмісту монооксиду вуглецю (CO), кисню $\left(\mathrm{O}_{2}\right)$ та відеокамера. Експериментальний зразок пожежного маячка розміщували по центру на підлозі біля задньої стінки димокамери напроти отвору спостереження, який знаходився на передній стінці димокамери на висоті 1,5 м по центру. 


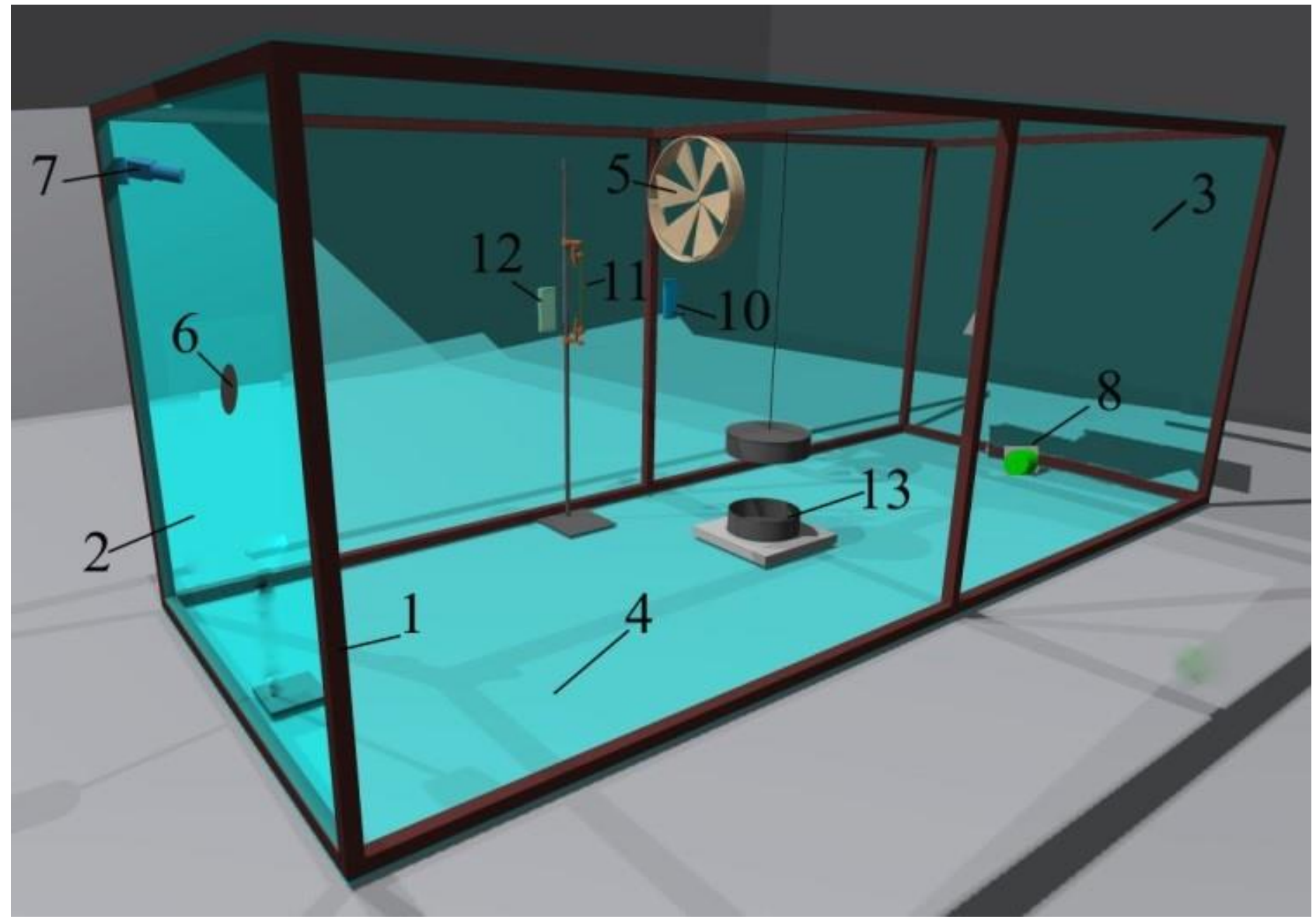

1 - каркас; 2 - передня вертикальна стінка; 3 - задня вертикальна стінка; 4 - зовнішня обшивка (брезент); 5 електричний вентилятор; 6 - отвір для візуального спостереження; 7 - відеокамера; 8 - пожежний світловий маячок; 10 - газоаналізатор для вимірювання вмісту монооксиду вуглецю $(\mathrm{CO})$, кисню $\left(\mathrm{O}_{2}\right)$ в об'ємі; 11 - вимірювальний комплекс оптичної щільності середовища (світлодіодний випромінювач CMD5050, фоторезистор, блок електричного живлення); 12 - цифровий міліамперметр

\section{Рисунок 4 -Схема димової камери та їі складові елементи}

Суть експериментальних досліджень полягла у наступному. При досягненні задимленого середовища величини оптичної щільності, що дорівнює $\mathrm{D}_{3 м}=0,032$ (визначається візуально за показами цифрового міліамперметра, значення якого має бути $(330 \pm 5)$ мкА, що відповідає величині нижньої межі задимленості високої щільності), візуально спостерігають за пожежним маячком. В разі відсутності візуального спостереження пожежного маячка потрібно його переміщувати в напрямку точки спостереження до моменту візуальної видимості світіння. За допомогою рулетки вимірюють відстань від точки спостереження до точки візуальної видимості світіння пожежного маячка.
B експериментальних дослідженнях використовували шість комбінацій світлодіодів у конструкції пожежного маячка, a caмe:

2 шт. червоного кольору 1 Вт, 2 шт. холодного білого кольору 1 Вт (зразок № 1);

2 шт. червоного кольору 1 Вт, 2 шт. теплого білого кольору 1 Вт (зразок № 2);

2 шт. червоного кольору 1 Вт, 2 шт. нейтрального білого кольору 1 Вт (зразок № 3);

2 шт. червоного кольору 1 Вт, 2 шт. холодного білого кольору 3 Вт (зразок № 4);

2 шт. червоного кольору 1 Вт, 2 шт. теплого білого кольору 3 Вт (зразок № 5);

2 шт. червоного кольору 1 Вт, 2 шт. нейтрального білого кольору 3 Вт (зразок № 6). 
В результаті проведення експериментальних досліджень встановлено, що для комбінацій світлодіодів №№ 1-6 забезпечується візуальне спостереження зразка світіння на відстані 6,0 м, однак найбільш видимим $є$ пожежний маячок із комбінацією світлодіодів № 4.

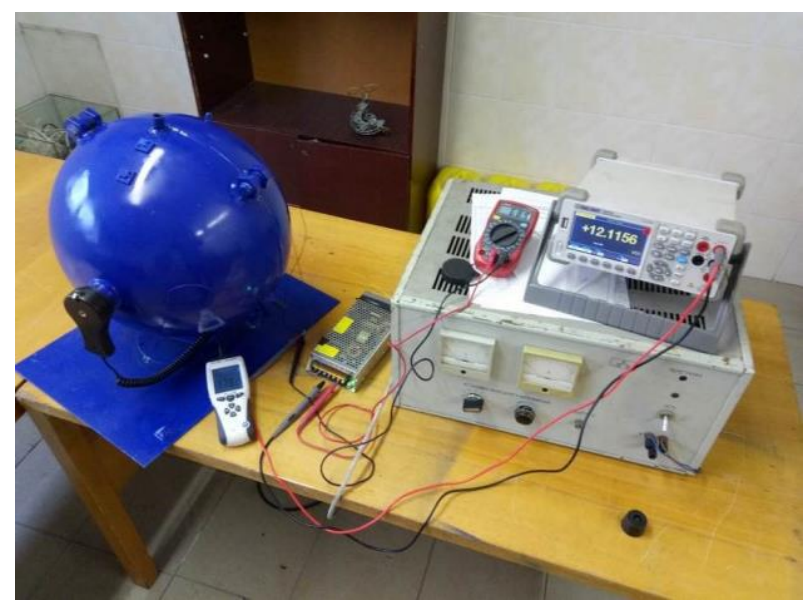

Визначено тривалість роботи пожежного маячка із комбінацією світлодіодів № 4 (до зменшення напруги до величини 2,8 В) - 4 год 20 хв.

Визначення світлового потоку комбінацій світлодіодів №№ 1-6 проводилось в фотометричній сфері згідно [5], зовнішній вигляд якої наведено на рисунку 5.

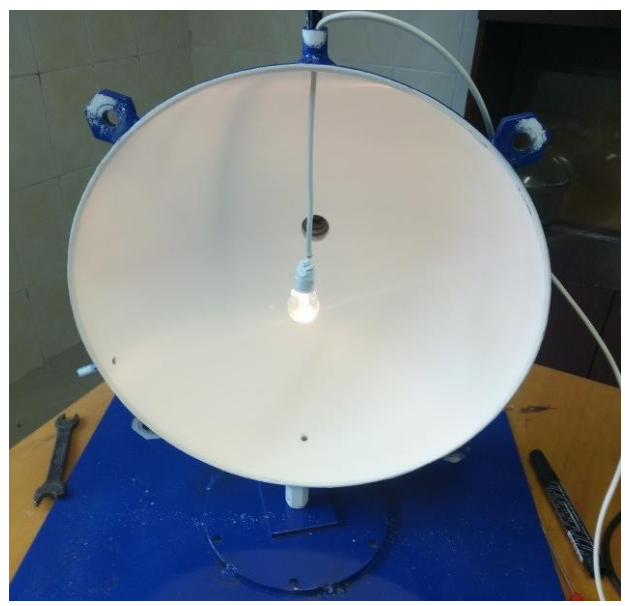

Рисунок 5 - Зовнішній вигляд фотометричної сфери

Результати експериментальних досліджень 3 визначення світлового потоку комбінацій світлодіодів №№ 1-6 наведено в таблиці 2 .

Таблиця 2 - Результати експериментальних досліджень з визначення світлового потоку

\begin{tabular}{|c|c|c|c|c|c|c|}
\hline \multirow{2}{*}{$\begin{array}{c}\text { № } \\
\text { комбінації } \\
\text { світлодіодів }\end{array}$} & Параметри & \multirow{2}{*}{$\begin{array}{c}\text { Освітленість, лк } \\
\text { Дослід } 1\end{array}$} & \multirow{2}{*}{$\begin{array}{c}\text { Освітленість, лк } \\
\text { Дослід } 2\end{array}$} & \multirow{2}{*}{$\begin{array}{c}\text { Освітленість, лк } \\
\text { Дослід } 3\end{array}$} & \multirow{2}{*}{$\begin{array}{c}\text { Середнє значення } \\
\text { освітленості, лк }\end{array}$} & \multirow{2}{*}{$\begin{array}{c}\text { Світловий } \\
\text { потік, лм }\end{array}$} \\
\hline & Напруга, В & & & & & \\
\hline 1 & \multirow{6}{*}{$\begin{array}{c}\text { Батарея Li- } \\
\text { Po, 3,7 B }\end{array}$} & 535,9 & 535,4 & 542,7 & 538,0 & 342,7 \\
\hline 2 & & 491,3 & 497,0 & 498,2 & 495,5 & 315,6 \\
\hline 3 & & 522,6 & 529,1 & 527,2 & 526,3 & 335,2 \\
\hline 4 & & 735,5 & 738,7 & 735,6 & 736,6 & 469,2 \\
\hline 5 & & 677,3 & 676,7 & 671,9 & 675,3 & 430,1 \\
\hline 6 & & 704,5 & 707,8 & 708,1 & 706,8 & 450,2 \\
\hline
\end{tabular}

Висновки. Враховуючи результати експериментальних досліджень сформовано основні технічні характеристики експериментального зразка пожежного маячка, a came:

- колір світіння - білий та червоний;

- світловий потік - від 400 лм;

- тривалість роботи - безперервний режим роботи не менше 4 годин.

Слід зазначити, що для ефективного використання пожежного маячка, враховуючи виявлені недоліки світових аналогів, визначено необхіні технічні характеристики експериментального зразка пожежного маячка, a саме:

- кількість маячків у комплекті - 3 шт.;

- режими роботи - мерехтливий;
- стійкій до механічного впливу;

- габаритний розмір - до Ø60 мм;

- напруга живлення - до 12 В;

- маса - не більше 0,3 кг;

- пило-вологозахищеність

для електронного блоку - IP-68.

Існує необхідність у проведенні досліджень, спрямованих на розширення класифікації оптичної щільності задимленого середовища 3 метою отримання більш точних експериментальних даних щодо визначення ефективності проникнення світлового потоку у задимленому середовищі із використанням інших електричних джерел світла із різною колірною температурою світіння та потужністю. 


\section{СПИСОК ЛІТЕРАТУРИ}

1. Настанова 3 організації газодимозахисної служби в підрозділах Оперативно-рятувальної служби цивільного захисту МНС України, затверджена наказом МНC України від 16.12.2011 № 1342.

2. Статут дій у надзвичайних ситуаціях органів управління та підрозділів Оперативно-рятувальної служби цивільного захисту, затверджений наказом МНС України від 13.03.2012 № 575 та зареєстрованій в Міністерстві юстиції України 25.05.2012. за № $835 / 21147$.

3. Провести дослідження та розробити експериментальні зразки пожежного устатковання з функцією світлового орієнтування / Скоробагатько Т. М., Чуян В. Ф., Присяжнюк В. В. Тимошенко О. М., Бенедюк В. С., Стилик І. Г., Куртов О. В.,

\section{REFERENCES}

1. Nastanova $\mathrm{z}$ orhanizatsii hazodymozakhysnoi sluzhby $\mathrm{v}$ pidrozdilakh Operatyvno-riatuvalnoi sluzhby tsyvilnoho zakhystu MNS Ukrainy, zatverdzhena nakazom MNS Ukrainy vid 16.12.2011 № 1342. (in Ukrainian)

2. Statut dii $\mathrm{u}$ nadzvychainykh sytuatsiiakh orhaniv upravlinnia ta pidrozdiliv Operatyvno-riatuvalnoi sluzhby tsyvilnoho zakhystu, zatverdzhenyi nakazom MNS Ukrainy vid 13.03.2012 № 575 ta zareiestrovanii v Ministerstvi yustytsii Ukrainy 25.05.2012. za № 835/21147. (in Ukrainian)

3. Provesty doslidzhennia ta rozrobyty eksperymentalni zrazky pozhezhnoho ustatkovannia $\mathrm{z}$ funktsiieiu svitlovoho oriientuvannia (2017) [Conduct research and develop experimental samples of fire equipment with the function of light orientation]. Zvit pro NDR, UkrNDICZ, K, 250 p. (in Ukrainian)
Грачов А. О., Мукшинова Т. О. // Звіт про НДР / УкрНДШЩ. К.-2017.

4. Верзилин М. М., Повзик Я. С. Пожарная тактика. М. ЗАО «Спецтехника НПО», 2007. - 440 с.

5. Тимошенко О. М. Загальні технічні питання щодо впровадження в Україні освітлювального та орієнтувально-світлового пожежного устатковання / О. М. Тимошенко, О. П. Борис, Т. М. Скоробагатько // Науковий вісник: Цивільний захист та пожежна безпека. - 2018. - № 2 (6). - С. 37-42.

4. Verzilin M. M., Povzik Ya. S. (2007) Pozharnaya taktika [Fire tactics]. ZAO «Spetstekhnika NPO», Moskow, 440 p. (in Russian)

5. Tymoshenko O. M., Borys, O.P., Skorobahatko T.M. (2018) Zahalni tekhnichni pytannia shchodo vprovadzhennia v Ukraini osvitliuvalnoho ta oriientuvalnosvitlovoho pozhezhnoho ustatkovannia [General technical issues as to introduction of illuminating and orienting and lighting fire equipment] Naukovyi visnyk: Tsyvilnyi zakhyst ta pozhezhna bezpeka, vol 2 (6), pp. 37-42. (in Ukrainian) 


\title{
JUSTIFICATION OF TECHNICAL REQUIREMENTS OF LIGHT BEACON
}

\author{
V. Benediuk, I. Stylyk, A. Tymoshenko, A. Grachev, O. Kurtov
}

The Ukrainian Civil Protection Research Institute, Ukraine

\section{KEYWORDS}

light beacon, light emitting diode, technical requirements, lighting performance, smoke chamber, photometric integrating sphere.

\begin{abstract}
ANNOTATION
The issue of the necessity of creating a fire light beacon is considered, due to which it is possible to improve the orientation of the fire and rescue workers in difficult conditions with limited visibility in buildings and premises with complex planning decisions and the light indication of the return path. An analysis of the technical parameters of existing light beacons has been carried out and it has been established that the requirements for their light indicators during use in zones with limited visibility are absent. The technical requirements for a fire light beacon are Justified taking into account the main disadvantages in existing models of light beacons. Experimental test equipment was developed for determining the light characteristics of artificial light sources (LEDs) when used in a smoky environment of different optical densities. Experimental studies of artificial light sources (LEDs with different color temperature of glow in the power of $1 \mathrm{~W}$ and $3 \mathrm{~W}$ ) are carried out in a smoky environment of different optical densities. The obtained experimental results were used in further work on the development of a fire light beacon. A 3D model was developed and an experimental sample was made using a 3D printer. The structure and principle of the experimental model of the light beacon, which differs from the existing world analogues, provides a visual observation of the glow 360 - relative to the vertical axis and has improved ergonomic parameters. The results of experimental researches on definition of light characteristics of beacons at work in a smoked environment of different optical density are resulted. Patent of Ukraine for utility model obtained for created sample. Developed and sent to the State Enterprise "UkrNDNTS" on the procedure for public comment project DSTU Fire equipment. Lightning equipment. Classification and general requirements.
\end{abstract}

\section{ОБОСНОВАНИЕ ТЕХНИЧЕСКИХ ТРЕБОВАНИЙ ПОЖАРНОГО МАЯЧКА}

\author{
В. С. Бенедюк, И. Г. Стылык, А. Н. Тимошенко, А. А. Грачов, А. В. Куртов
}

Украинский научно-исследовательский институт гражданской защиты, Украина

\section{КЛЮЧЕВЫЕ СЛОВА}

пожарный маячок, светодиод, технические требования,

светотехнические характеристики, дымовая камера, фотометрическая интегрирующая сфрера.

\begin{abstract}
АННОТАЦИЯ
Рассмотрен вопрос о необходимости создания пожарного маячка. Обоснованно технические требования к пожарному световому маячку с учетом основных недостатков в существующих моделях световых аналогов. Описаны устройство и принцип работы экспериментального образца пожарного маячка. Приведены результаты экспериментальных исследований по определению светотехнических характеристик пожарных маячков при работе в задымленной среде различной оптической плотности.
\end{abstract}

